\title{
Gridlock: A Theoretical and Applied Critique Using the Family and Medical Leave Act
}

\section{By Nicholas A. J. Stengel}

\begin{abstract}
Politicians, media, and the public use the term "gridlock" to refer to the crush of competing interests in the policy process. Gridlock, however, is not a phenomenon that can be objectively identified or addressed. Rather, it is a catch-phrase used by partisans and pundits. Using other theories of political conflict and a case study of the Family and Medical Leave Act of 1992, this article shows that political discou'se would be better served if gridlock was not used as an analogy for perceived legislative troubles.
\end{abstract}

\section{Introduction}

Griclock is the epithet on the tongues of disgruntled voters who want their lawmakers to make laws. Politicians, journalists, and pundits often create the impression that government impedes progress. Some force or set of forces - is at work on Capitol Hill that prevents common-sense legislation from becoming law. Positions can become so entrenched that government literally shuts down. Without news to report on legislative action; journalists who need stories and politicians who need to point fingers have created a fiction known as gridlock. Books have been written on the subject and university students have written papers on the phenomena. But is it useful? Is gridlock an idea that casts light on the problem of legislative inaction and shows a way forward, or is it a clever phrase good only for demagogues who mischaracterize the nuances of the legislative process for personal political gain? This article seeks to go beyond the jingoism of the term in order to identify more useful explanations of the phenomena it has been used to describe.

\section{Gridlock - Definitions and History}

At an intersection of two roads, too many vehicles wait to cross at a red light: Once the signal turns green, a few more cars than can make it to the other side attempt to clear the intersection. As a result, cars remain in the intersection, blocking the cross traffic, and gridlock occurs. In policy terms, two or more sets of political actors rush forward, trying to accomplish some agenda, while the policy environment dictates that none can succeed unless someone yields. This definition of gridlock correlates closely with the term's first recorded usage on Capitol Hill.

An archive review of major daily newspapers does not show use of the term gridlock with regard to congressional action or inaction prior to September 1982. During that summer, however, arguments raged on Capitol Hill over economic policy. The Federal Reserve Board and the Congress were at cross purposes, with the Fed acting against inflation by raising interest rates and the Congress fighting economic stagnation by pumping money into the economy. These contradictory actions were labeled "economic gridlock" in a New York Times editorial (1982).

Shortly after its political introduction, the term gridlock took on new life. Senate business was at a standstill as Republicans pursued four votes to break a filibuster over a school prayer bill. Unwilling to let the bill die, leadership repeatedly filed cloture petitions, prompting Senator Dale Bumpers (D-Arkansas) to com-

Nicholns A. J. Stengel holds a Master's Degree in Public Administration from The George Washington University. He works for The Urban Institute as a Reasearch Associate in the Center on Nomprofits and Philanthropy, where he has authored papers and book chapters on nonprofit statistics and policy. Prior to working for The Urban Institute, Stengel was a grassroots organizer and activist for nonprofit issues. 
plain, "how many times do we have to vote on this? What advantage is there to being on record 10 times instead of nine?" (Peterson, 1982).

The unwillingness of one party to yield on the issue prevented other issues from being placed on the legislative calendar. In the words of Senate Majority Leader Howard Baker (R-Tennessee), Congress had created "legislative gridlock" (Roberts, 1982). Consider the metaphor of the intersection where Democrats are already blocking the intersection or policy space with the filibuster. Republicans could wait for the intersection to clear by accepting defeat and acknowledging that the Democratic agenda of rigorous separation between church and state had prevailed. If they waited at the intersection, the field would be clear for a new agenda. Instead, however, the Senators moved in and forced vote after vote.

Baker's concept of gridlock could have developed into a valid theory of legislative behavior. Unfortunately, the rest of the decade witnessed a slow drift, on Capitol Hill and in the popular press, to another, more diluted vernacular. The press and the Clinton Administration tended to portray gridlock as the frustration or defeat of popular bills, usually as a result of divided government.

Gridlock served as the explanation for legislative inaction when the Democrats controlled the Congress and the Republicans held the White House, For a while, of course, it seemed like a fine situation for all concerned. Blame would shift up and down Pennsylvania Avenue without anyone taking responsibility. The electorate seemed to like it, too. In the famous formulation of Charles McDowell of the Richmond Times-Dispatch, voters sent Democrats to Congress so they would get what they wanted and Republicans to the White House so they wouldn't have to pay for it. True, for a time divided government did manage to produce some useful legis- lation and policy. But by 1992 McDowell observed, things really were at a standstill (1993).

Legislative action may well have been stymied; however, an exploration of the Family and Medical Leave Act (FMLA) reveals that gridlock does not adequately explain legislative inaction.

\section{Critique of the Theory of Gridlock}

Theories can help clarify and distill actions taken by political actors. The problem with the concept of gridlock is that it does the opposite: it obscures factors behind legislative inaction. For example, gridlock cannot help explain how a decision to hold a floor vote, though it may be certain to fail, could be prompted by a desire to raise public consciousness on an issue. It tells us only that the public should be angry that Congress did not get something done and that the electorate should oust incumbents from office for not getting it right the first time.

One of the most powerful critiques against any theory of gridlock is the lack of a coherent and commonly accepted definition of the term. Nearly all the perceived ills of government have been labeled as gridlock at one time or another. For example, "where financial interests are at stake, the gridlock is not caused by a clash between a Democratic Congress and a Republican administration. Rather, Congress itself is logjammed owing to a distortion of loyalties by campaign contributions" (Karpinsky, 1992, 18). In another example, Jonathan Rauch argues that so many competing interest groups have access to lawmakers that majorities are almost impossible to obtain (1994). Thus, it is not that politicians are beholden to special interests. Instead, it is that there are too many interests all together. In yet another example, many pundits argue that gridlock is simply caused by intractable party divisions (Blitzer, 1999). Without a com- 
mon definition or causal understanding, how can the theory be evaluated or used to understand legislative behavior?

Another, more fundamental, problem with the gridlock theory is that it assumes that the legislative process is initiated only to enact law. This is not the case. "Getting things done" on Capitol Hill encompasses more than making laws. Aside from an effort to raise consciousness seen in the school prayer example above, members may introduce potentially unsuccessful bills for myriad reasons: getting elected, changing or maintaining the makeup of the Congress or the Executive, enhancing re-election bids, advancing an issue for development of future bills, or log rolling (voting for a proposal to secure a favor from another member).

The prima facie criticism of this theory is that gridlock is a subjective concept. That is, one person's gridlock is another's good legislative behavior. During the debates surrounding FMLA, those in opposition to the bill argued that granting leave to employees who have sick family members placed an onerous burden on the business community. When the bill sat in committee or was passed over for debate, business interests did not blame gridlock-they called it responsible lawmaking. A robust political theory cannot rest upon such subjective criteria.

These examples help suggest that gridlock may not be a valid or useful theory or model for understanding the political and legislative process. Rather, it is an excuse to point fingers, anger the electorate, and generate fodder for reporters. To help demonstrate that gridlock is not a rigorous theory, and merely a rhetorical tool, one can trace the path of the Family and Medical Leave Act. This examination will clarify in practice what the theoretical critique has already argued: gridlock is a weak concept that should give way to more complete and informative ideas.

\section{If This Isn't Gridlock, Nothing Is}

The Family and Medical Leave Act (FMLA) is a brief, straightforward law. The basic provision allows employees to take up to 12 weeks of unpaid leave to care for a new child or sick family member or for personal illness. Health care benefits continue during the leave and the employee cannot be fired for using the benefit.

The text is simple, but the story behind its adoption is not. The campaign to win passage of the FMLA was a nine-year saga of legislative battles featuring two presidential vetoes. When supporters of the bill finally prevailed, FMLA became the first law signed by President Clinton. At that time, Congress watchers declared, "... the wait is over for the Family and Medical Leave Act. The new law ... marks an end to a decade of government gridlock on a major social issue"(Outlook, 1993). The primary Senate sponsor, Christopher Dodd (D-Connecticut), praised the bill's passage: "gridlock is over. ...Here is an example of what Congress and the White House can do in a bipartisan way to pass legislation (Dewar, 1993)."

Pundits did not rest long, however, before declaring the return of gridlock, even though the presidency and the Congress were in Democratic hands. (Frustration with a unified government may have helped give way to Republican control of the House and Senate in 1994.) Despite the passage of significant legislation in the mid1990s, public discontent seemed constant. So did use of the term gridlock.

The public was angry and perceived the government to be gridlocked over FMLA. But its opinion did not change after passage of the bill. Many theories exist that more thoroughly explain these phenomena than the label of gridlock. By tracing the path of the FMLA, a veritable poster-child for the term (Opinion, 1993), from idea to law, these alternative theories can be explored. For each "stumbling point" where 


\section{GRIDLOCK: A THEORETICAL AND APPLIED CRITIQUE}

one might be tempted to declare gridlock exists, a better theory applies. If it can be shown that gridlock does not apply to FMLA, it could be said that gridlock does not exist as a valid and testable political theory-indeed, gridlock is just a buzzword. A theory should either explain a phenomenon or predict future behavior. This case study argues that the theoretical term gridlock, as such, does neither.

\section{The long and winding road of FMLA - Early Years}

Just as it may take, as John F. Kennedy once said, more than one generation to change the way people think, often it takes more than one congress to pass a meaningful bill. Members may have to offer ideas that are ignored and then campaign on them as issues. Members may return and offer those issues as bills repeatedly until the measures are considered. Then the Members have to push the bills "to the brink again and again until they get over" (Elving,1995,183).

The roots of federal legislation on family leave began with Howard Berman (D-California), who in 1978 authored a law in the California Assembly providing four months of unpaid leave to new mothers. In 1984, Berman was a member of the 98 th Congress when a Federal District court voided the law, declaring that special treatment of mothers violated the Civil Rights Act of 1964. In his new capacity as a national legislator, Berman started the process of creating a federal version of the leave policy that would nullify the ruling.

Berman gathered a small drafting committee that included advocates from such groups as the Women's Legal Defense Fund, the Junior League, and the League of Women Voters. Discussions on the form of a bill spanned the congressional session. The main issue was whether to frame the bill as a targeted benefit to new parents or as a broader mandate that would affect all workers. Berman believed that a narrow mandate only benefiting mothers would appeal to prolabor and pro-life concerns in Congress, and would pass quickly. However, lobbyists in the group wanted to push for a broader construction. Committee discussions set the stage for two theories that counter gridlock models: E. E. Schattschneider's concept of scope of contagion (1983) and James Q. Wilson's allocation of costs and benefits for a given policy (1980).

Schattschneider argues that "the outcome of all conflict is determined by the scope of its contagion. ...[T]he most important strategy of politics is concerned with the scope of conflict (1983)." To pass the FMLA, the bill's sponsors would have to overcome staunch opposition from the business lobby and a Republican White House, and would need to attract a far larger support base than expectanct and new mothers. If the benefit extended to more people, passage would arguably be easier.

Wilson outlines a policy typology set on a four-square grid bounded by the concepts of who pays and who benefits, the few or the many. Based on concentration or diffusion of costs and benefits, the potential policitical ramifications-the scope of contagion-is altered. Applying this theory can be problematic since it depends on several subjective factors. It can, however, be useful in explaining how proponents try to cast and recast issues as they search for allies. Finding the right mix of activated proponents and inactive opponents is the goal of all lobbying campaigns. In the case of FMLA, opponents tried to cast the issue as benefiting a small group of people who were already privileged and compensated by the economy in general. Proponents saw the bill as helping all families and being paid for by "big business." (How an issue is perceived will activate different networks of activists, while dampening the interest of other groups.) 
Discussions on the best way to construct family leave legislation continued into the 99th Congress in 1985. The Junior League held a conference to raise public consciousness on the issue, and members of the ad hoc drafting committee did not yet agreet on the approach they should take. Both sides, however, agreed not to push two versions, for fear of dividing supporters.

On April 4, 1985, Representative Patricia Schroeder (D-Colorado) introduced H.R. 2020 on behalf of the drafters. As proposed, the Parental and Disability Leave Act would provide 18 weeks of unpaid leave for parents, (regardless of gender) of newborn or newly adopted children. It would also allow employees to take up to 26 weeks for temporary disabilities, personal illness, or sick children. Employers would be required to continue paying health insurance and other benefits. Upon returning from leave, employees would be guaranteed their old job or a comparable one. The bill applied to employers of all sizes (H.R. 2020, 1985). Analyzed against the two theories described above, it is clear that the bill's framers cast the benefits widely in hopes of attracting supporters to their side, including traditional Republican constituencies such as pro-family and pro-life groups. Meanwhile, they hoped to downplay perceptions of cost to the business community, a formidable opponent of the legislation.

In October, a hearing was held with small audiences and an even smaller panel on the dais. None of the chairpersons or the ranking members were present when the meeting was gaveled to order. There was no companion Senate bill, no ranking cosponsor, and no real hope of moving forward without changes and a concerted education effort.

Berman and Schroeder possessed the technical skills and the personal interest to begin the process, but to get votes and action supporters knew they needed to enlist a powerful leader. They convinced Representative Bill
Clay (D-Missouri) to take that role. Clay would not enjoy the same affinity with feminists that Representative Schroeder possessed, but he could gain access to power centers not available to her. He could also convene a hearing or mark-up session in his own subcommittee, all but assuring a full committee mark-up before the end of the 99th Congress. (Elving, 1995).

In addition to seniority, Clay had ties to organized labor, adding to existing supporters such as feminists, traditional family organizations, and dual-income workers. He essentially enlarged the scope of contagion. (His efforts did not create gridlock since the bill moved forward and attracted supporters and champions.) With this powerful champion, a new bill was drafted. This version, H.R. 4300, addressed specific objections from labor and omitted language supporting coverage for abortions, which paved the way for support from the U.S. Catholic Conference.

While cosponsors slowly gathered in the House, the Republican-controlled Senate proved a bit more problematic. A sponsor had appeared in the person of Senator Christopher Dodd (D-Connecticut). Dodd was a member of the committee of referral, Labor and Human Resources, and introduced S. 2278, but little action took place during the remainder of the 99th Congress. Among other things, Dodd was just testing the waters for votes down the road.

In the House, Representative Clay's initiative attracted the first signs of real opposition. In a June markup, the opposition presented its case with Representative Marge Roukema (R-New Jersey) at the vanguard. From the Wilson perspective discussed above, she labeled the bill an onerous federal mandate in an era where free markets should prevail.

Ideology played a powerful role in the promotion, evolution, and "stalling" of the Family and Medical Leave Act. Both sides of the debate were driven by 


\section{GRIDLOCK: A THEORETICAL AND APPLIED CRITIQUE}

core principles and values. Ideologically, business has been uncomfortable with taking responsibility for the families of workers and has generally opposed the concept, if not always the reality of government intervention (Kaitin, 1994).

In addition to emphasizing the costs, especially to small business, Roukema sought to portray the benefits as extending only to the upper class. Who else could afford to take 18 weeks but families with two incomes? In an attempt to make the amended bill unattractive even to its supporters, Roukema offered a number of amendments cutting time and exempting all but the largest employers.

Her attempts to change the bill were ultimately unsuccessful but many compromises were necessary to build enough support for passage through Committee, including an exemption for businesses with fewer than 15 employees. Another amendment changed the name to the Family and Medical Leave Act. Perhaps the most important compromise, however, was extension of the bill's benefits to permit leave to include caring for other sick family members-elderly parents in particular. This addition brought the powerful American Association of Retired Persons into the support coalition.

Still, by the time FMLA was brought to the House floor for debate, time was short and the outlook appeared bleak.

As a first-time bill, reported late in the session, fam-: ily leave was well back in the queue of pending legislation. The leadership knew that active resistance to H.R. 4300 had only increased after the mark-up. Members were hearing from small-business people in their districts, lobbyists in Washington, and other Members who opposed mandated family leave (Elving, 1995).

Furthermore, House leaders would not push a vote on a bill without a Senate companion in position to become law. A Rules Committee decision to grant an open rule finally discouraged opening debate and the session ended without a vote because the rule would open the measure to additional burdensome amendments.

Gridlock did not occur for FMLA in the 99th Congress. The bill was slowly being reshaped and moving forward, not stalled or frustrated. It did not reach the end of the legislative process, but progress was made a significant political goal so early in a bill's life. Compromises were made, coalitions formed, champions sought and won, arguments presented, and lawmakers persuaded. The process would, however, need to begin anew in the 100th Congress in 1987.

\section{Progress in the $100^{\text {th }}$ Congress}

The opening of the 100th Congress was marked by Democratic recapture of the Senate. As if to punctuate the changing of the guard, Senator Dodd placed FMLA into the box of the Clerk of the Senate on the first day of the session. Action was quickly taken up in the House as well. The earnest interest of bill sponsors to get a floor vote was noticed by the opposition coalition, who prepared for the fight. Sensing a large scope of contagion on the other side, Dodd and his staff devoted eight months to hearings on the merits of the bill. This delay was exceptional but can be explained far better by Wilson and Schattschneider than any notions of gridlock. Dodd attempted to gather support-the more people who support a position, the more likely that position is to prevail. Likewise, the cross-country hearings allowed direct contact with locals (and local media) to cast FMLA as entrepreneurial by Wilson's typology, with benefits distributed to many families at a cost to relatively few large businesses.

The issue's time away from Capitol Hill also gave the General Accounting Office (GAO) an opportunity to complete a study that would counter opponents' estimates of FMLA's enormous cost to the business community. 
Multi-billion dollar horror stories had frightened many pro-family Republicans who might support the idea of family leave but not at any cost. Again, Wilson's typology is in evidence behind the dueling studies. The bill's opponents argued that huge costs would outweigh the benefits. The GAO report showed differently. With the amount of money involved, these cost estimates should not be understood as weapons but vital information for uncommitted lawmakers to use in making up their minds. According to the GAO, instead of billions, FMLA would cost businesses no more than $\$ 500$ million (1989).

Supporters in the House had been hard at work, not rallying against opposition and creating gridlock but gathering cosponsors. An important victory came when Representative Roukema agreed to support the bill. She had previously introduced her own version of family leave as H.R. 284. Winning her support required compromising the length of leave and setting the small business exemption at 50 employees. While this represented a large concession, the exemption concentrated the costs of the bill to approximately 5 percent of all businesses. At the same time, those few companies employed about 60 percent of the labor force-a very attractive place on Wilson's typology grid-and support continued to grow for the policy. Anew Senate bill, S. 2488, was introduced that closely mirrored the compromise.

Increased support, much of it bipartisan, did not mean that the bill would enjoy easy passage. At the end of the session, a Senate vote that ran afoul of procedural wrangling failed to recommit the bill to committee. Disheartened, the bill's House supporters decided to wait until the next session, hoping that a Democratic White House would help ease passage.

Senate defeat came at the hands of Bob Dole (R-Kansas), whose strategy of procedural frustration is best summed up by Congressman John Dingell. "If you let me write the procedure, and I let you write the substance,
I'll [beat] you every time" (National Review, 1987, 24). Defeating FMLA by procedure might viewed as aclassic case of gridlock. But in creating the Congress, the Foundering Fathers included rules that allow a minority to prevail. Strategic procedural action, then, is less an example of gridlock than an example of the deliberative policy-making envisioned by the Founders.

Rules and procedures affect what Congress does and how it does it....Above all, the rules and organization of Congress create numerous decision points through which legislation must pass in order to become law. As a result, congressional decision-making presents many opportunities for members to defeat bills they oppose. (Oleszek, 1996, 23)

Some scholars point to the numerous opportunities to defeat a bill as one cause of gridlock. If all available access points find users, then the system grinds to a halt and nothing is passed. Jonathan Rauch popularized this argument, called hyperpluralism (1994). His theory is countered, however, by quantitative studies showing that while the number of bills introduced has decreased, average length of legislation has increased, offsetting the decline in volume (Davidson, 1996).

In addition, Congress has entered a new phase of lawmaking centered on maintaining a balanced budget. An environment of zero sum (or less than zero sum) budget restrictions has a self-limiting effect on the passage of legislation because no realistic way exists to pass many measures without violating spending agreements. The meta-environment of Congress is such that rules and procedures create many points for the defeat of a proposal; at the same time, Congress is less inclined to consider more proposals. The manifestation of these phenomena could be called gridlock, but the other theories described above are more robust and precise. 


\section{GRIDLOCK: A THEORETICAL AND APPLIED CRITIQUE}

\section{The Bush Administration}

The 101st Congress was the first to see a concerted effort by both chambers to take a vote and make FMLA law. The support coalition was encouraged, having Republican cosponsors at the outset for a bill that seemed on the rise. In addition to Roukema in the House, Dodd had managed to persuade Senator Orrin Hatch (R-Utah), senior Republican on the Labor Committee, to support family leave. The proposals, now S. 345 and H.R. 770, seemed on a fast track. Despite its prior defeat, newly elected President George Bush had never spoken out against family leave. While in the Senate, Vice President Dan Quayle had even flirted briefly with cosponsorship. Many supporters felt that the first session would end with a newly signed law, and the strategy for floor debate was constructed toward that end. This time, the coalition was playing to win.

Hearings for the proposals took place early in the session, highlighted by converts to the support coalition and several important compromises. First and most important, small business opposition began to disappear due to the new 50-employee threshold. Second, the bill was amended to exempt teachers, removing a powerful argument that family leave might hurt children. In addition, to counter the perception that FMLA was just a "yuppie" benefit (a very unlovable group upon which to grant concentrated benefits), several witnesses of middle and lower class were brought to the hearings to recount having to choose between family obligations and their jobs. Their situations were not those of a spouse in a two-income family having the luxury of taking time off from work to care for a newborn. Rather, the most important beneficiaries of FMLA might well be people without options or those who have to choose between work and family obligations.

A favorable rule was followed by a vote in the House on May 10,1990. The first and only House vote showed few traces of gridlock and passed 237-187, with 39 Republicans voting in support of the measure. In the Senate, there was some delay because Dodd was involved in several high-profile bills that took him away from family leave. Neither opposition nor gridlock, however, were the cause for delay. To save time, the Senate substituted House language for its version and obviated the need for a Conference Committee. Detractors of Dodd's bill had correctly assumed that it would pass and had turned their attention toward securing a veto and so let the measure proceed on a voice vote with no recorded opposition. And while the President remained silent, his Chief of Staff, John Sununu, promised there would be no signature (Elving, 1995).

The veto promised by Sununu was delivered, and its wording seemed scripted from the opposition coalition's fact sheets:

In vetoing this legislation with its rigid, federally imposed requirements, I want to emphasize my belief that time off for a child's birth or for family illness is an important benefit for employers to offer employees. I strongly object, however, to the Federal Government mandating leave policies for America's employers and work force.

(Bush, 1990, 1030)

Gridlock? It may be a question of perspective. From the perspective of large employers, this veto meant that the system was working as it should. Proponents of family leave, however, were beginning to feel that the legislature was unfairly blocked by the veto. The coalition would have to go further $r_{r}$ and campaign on the issue, if necessary, to change the president's mind-or await a change inadministrations. Further, many supporters of the ideas behind family leave were not necessarily disappointed by the measure's failure. The bill's provisions for leave time had been gutted, and it contained so many 


\section{POLICY PERSPECTIVES}

exemptions and exceptions that it hardly resembled its original mandate.

\section{Another Veto}

In 1991, FMLA began again on what appeared to be a path to veto. In reality, the situations in the 101st and 102nd Congresses were very much different, although both are in keeping with the theories of legislative behavior previously described.

Congressional leaders sent a clear signal that FMLA was important by reserving symbolically low bill numbers, H.R. 2 and S. 5. Senator Dodd and Representative Clay would be supported and assisted by leadership. More compromises were also being worked to make the bill more palatable to the legislature. Compromises were struck that lengthened the number of hours an employee would have to work before being eligible. Also, an exemption for "key" employees who a company could not do without, as well as scaled back penalties for noncompliance, were included. These changes secured quick Committee approval and a very successful Senate vote. The tally was 65-32, with three supporting senators not casting votes-seemingly veto-proof. The House also acted quickly, scripting a very favorable rule and gaining additional votes compared to the 1990 totals. The House vote count was $265-163$, with 40 Republicans voting in support of the measure.

Several factors, supporters hoped, would result in a Presidential signature. First, the leadership had waited until John Sununu had resigned before sending the bills to conference to work out minor differences. It was hoped that the President's new Chief of Staff, Sam Skinner, would not be an impediment. Also, the President enjoyed stratospheric approval ratings following the Gulf War. If he had wanted to sign the bill but was worried about re-election in 1992, he enjoyed several layers of political cover now.
Unfortunately, by the time the bill came to his desk, the President's popularity was falling faster than it had risen. The economy was faltering and he was facing a potentially serious challenge for renomination in the person of Patrick Buchanan. His veto message underscored these concerns.

America faces its stiffest economic competition in history. If our Nation is to succeed in an increasingly complex and competitive global marketplace, we must have the flexibility in our workplaces to meet this challenge. We must ensure that Federal policies do not stifle the creation of new jobs or result in the elimination of existing jobs (Message from the President, 1992).

The idea of passing FMLA again in the second congressional session was floated briefly, but supporters feared was that another futile vote simply for electoral gain would threaten the bipartisanship of the coalition and harm the bill's long-term chances. Thus, the 102nd Congress ended without passage of a family leave act.

In fact, citing President Bush's second veto as an example of gridlock is actually counterintuitive. Even if the president was wrong in believing the economy would suffer, he made an unpopular choice because he believed it was the correct course. In the face of a faltering economy, a new mandate was, in the president's mind, the last thing upon which a responsible executive should focus. If the bill's congressional supporters had pressed for a third vote, one might have a case for gridlock. But here all parties seem to be acting responsibly, if at cross-purposes.

President Bush's decision to veto the bill can be understood more completely from a theoretical construct; the idea that business mandates are the most difficult laws to pass in America. Struggles over employment policy are fundamentally about where to draw the line 
GRIDLOCK: A THEORETICAL AND APPLIED CRITIQUE

demarcating the appropriate role of government in the economy and its obligations toward individual citizens. The American structure of values reveals a tension between democracy and equality, on the one hand, and capitalism and individualism on the other (Muccuaroni, 1990).

In other words, a much larger scope of contagion would have to coincide with a more healthy economy and lower estimates of FMLA's costs before President Bush would be moved to act. It was not gridlock that prompted the President's veto; it was his understanding of the role of government in a time of economic downturn.

\section{Public Law 103-3}

When the 103rd Congress began in 1993, with Bill Clinton in the White House and the economy in recovery, the Family Leave legislation seemed back on track. FMLA submissions began on January 15, with H.R. 1 and S. 5. Committee work was perfunctory and a Senate vote, on February 2, was 71 to 27 in favor. The House substituted Senate language and held its vote the next day-247 to 152 - slightly less than the vote in the 102nd Congress, but that year's election had shown a net gain of seats for Republicans. There was a brief moment when Republican leaders threatened to attach a "poison pill" amendment that would ban gays in the military but they never followed through on the threat. On February 5th, 1993, President Clinton signed FMLA, Public Law 103-3.

Three weeks had passed from bill to public law and there was no gridlock in sight. Believers in the theory might be tempted to point to quick passage once government was united under Democratic rule. However, theories far more precise and powerful than gridlock provide a better explanation.

\section{Conclusion - Leave gridlock to the demagogues}

An examination of conceptual flaws in the theory of gridlock and its lack of traction on what should have been an easy application to the Family and Medical Leave Act suggest that gridlock is not viable as a political theory. Of course, bills get delayed and take years to pass before they become law. And, there is significant public anger directed at lawmakers who do not pass seemingly popular legislation. A panoply of theories, however, better serve to explain the frustration and delay in passing legislation.

Schattschneider and Wilson combine to show how advocates on both sides of a legislative proposal will attempt to cast and re-cast costs and benefits so they can build support for their positions and erode the opposition. As previously noted, President Kennedy advised that it takes many years to change minds and policy and we should expect slow progress. Muccuaroni agrees, noting that the American Protestant work ethic has always made policies affecting employers very difficult to pass. Further, a number of theories suggest that the Constitution itself was designed to promote deliberation over expediency.

Many other procedural issues can contribute to a perception of gridlock, including selection of champions, the meta-environment, the economy, and the latest polls. There are many other perfectly valid theories for why legislative progress is too slow for its critics in the media and in the public. Each of them, alone or together, is better at telling the story of inaction than the word gridlock. Besides not being able to answer questions of why progress does not occur, where the problem lies, or even how to fix it, gridlock can lead to frustration as a theory because it creates no understanding of legislative processes. 


\section{POLICY PERSPECTIVES}

Rather than treating gridlock as a tangible and useful idea in the political lexicon, public discourse would be better served by an attempt to understand why the policy process seems to bog down and how to move bills forward. Gridlock tells us nothing of value, it opens no doors, and creates no understanding. In the final analysis, the term itself is part of the problem. There is an old adage that people should not inquire too much about the makings of either sausage or laws. But just as Upton Sinclair proved we should care very much about what goes into our food, the complexities of policy formulation are also important and should be described by more than one empty term.

\section{REFERENCES}

Blitzer, W. (1990). http://www.cnn.com/ALLPOLITICS/stories/1999/03/09/president.2000/transcript.gore/.

Brody, R., and Bryant, M. (April 1994). "The FMLA in real life." Faulkner and Gray Small Business Reports, 45.

Bush, G. (1990). "Message to the House of Representatives Returning Without Approval the Family and Medical Leave Act of 1990." Public Papers of the Presidents of the United States. Washington, DC: GPO, 1990. 1030-1031.

California Federal Savings \& Loan Association et al. v. Guerra. 479 U.S. 272 (1987).

Davidson, R. (1996). "The presidency and congressional time." Rivals for power: Presidential-congressional relations. Thurber, J. ed. Washington, DC: CQ Press.

DeGregorio, C. (1997). Networks of champions: Leadership, access, and advocacy in the U.S. House of Representatives. Ann Arbor, MI: University of Michigan Press.

Dewar, H. (5 February 1993). "Congress passes family leave." The Washington Post, A1.

Ehrenhalt, A. (November 1992). "The no-man's land of family policy." Governing Magazine.
Elving, R. (1995). Conflict and compromise: How congress makes the law. New York, NY: Simon \& Schuster.

Kaitin, K. (1994). Congressional responses to families in the workplace: The family and medical leave act of 1987 1988. More than kissing babies? Current child and family policy in the United States. Jacobs, F., Davies, M. Westport, CT: Auburn House.

Kamarck, E., and Galston, W. (1996, March). "Putting children first." The Mainstream Democrat, 6.

Karpinski, G. (1992, October 13). "Gridlock inside congress," Christian Science Monitor, 18.

Muccuaroni, G. The political failure of employment policy, 1945-1982. Pittsburgh, PA: University of Pittsburgh Press.

National Review (February 1987), 24.

Oleszek, W. (1996). Congressional procedures and the policy Process. Washington, DC: Congressisonal Quarterly.

Opinion Editorial. (1993, February 18). The Washington Post, A18.

"Outlook; Science \& Society." (1993, February 15). U. S. News and World Report, 28.

Peterson, B. (1982, September 23). "Tempers flare on prayer filibuster." The Washington Post, A1.

Rauch, J. (1994). Demosclerosis. New York, NY: Random House.

Roberts, S. (1982, September 23). "School prayer advocates lose third vote in Senate." The New York Times, Late City Final Edition, B17.

Schattschneider, E. (1983). The semisovereign people: $A$ realist's view of democracy in America. Hinsdale, NY: The Dryden Press.

"The gridlocked economy." (1982, June 21). The New York Times, Late City Final Edition, A18.

United States. Cong. House. Committee on Education and Labor. Subcommittee on Labor-Management Relations. (1989). Hearing on H.R. 770, The Family and Medical Leave Act of $1989.101^{\text {st }}$ Cong. 1 st sess. 101-2. Washington, DC: GPO. 
Cong. House. (1995). Parental and Disability Leave Act. US $99^{\text {th }}$ Cong., $1^{\text {st }}$ sess. HR 2020.

. Cong. House. (1986). Parental and Medical Leave Act. US $99^{\text {th }}$ Cong., $2^{\text {nd }}$ sess. HR 4300.

. Cong. Senate. (22 September 1992). Message from the President of the United States Returning Without my Approval S. 5, the Family and Medical Leave Act of 1992. $102^{\text {nd }}$ Cong. $1^{\text {st }}$ sess. Washington, DC: GPO.

- Cong. Senate. (27 January 1993). The Family and Medical Leave Act of $1993.103^{\text {rd }}$ Cong. $1^{\text {st }}$ sess. 103-3. Washington, DC: GPO.

Walsh, K., Borger, G., Roberts, S., and Friedman, D. (2 July 1992). "Bush's veto strategy." U.S. News and World Report, p. 18.

Wilson, J. (1980). The politics of regulation. New York, NY: Basic Books. 